\title{
Polymerase Chain Reaction
}

National Cancer Institute

\section{Source}

National Cancer Institute. Polymerase Chain Reaction. NCI Thesaurus. Code C17003.

A method for amplifying a DNA base sequence using multiple rounds of heat denaturation of the DNA and annealing of oligonucleotide primers complementary to flanking regions in the presence of a heat-stable polymerase. This results in duplication of the targeted DNA region. Newly synthesized DNA strands can subsequently serve as additional templates for the same primer sequences, so that successive rounds of primer annealing, strand elong ation, and dissociation produce rapid and highly specific amplification of the desired sequence. PCR also can be used to detect the existence of the defined sequence in a DNA sample. 